\title{
Evaluation of Atriplex lines for selenium accumulation, salt tolerance and suitability for a key agricultural insect pest
}

\author{
D.B. Vickerman ${ }^{\mathrm{a}, *}$, M.C. Shannon ${ }^{\mathrm{b}}$, G.S. Bañuelos ${ }^{\mathrm{c}}$, C.M. Grieve ${ }^{\mathrm{b}}$, J.T. Trumble \\ a Department of Entomology, University of California, Riverside, CA 92521, USA \\ ${ }^{\mathrm{b}}$ USDA, ARS, Salinity Laboratory, Riverside, CA 92507, USA \\ ${ }^{\mathrm{c}}$ Water Management Research Laboratory, USDA, ARS, Fresno, CA 93727, USA
}

Received 21 July 2001; accepted 4 December 2001

\begin{abstract}
"Capsule": Five salt tolerant lines of the plant Atriplex were identified which were also resistant to beet armyworm, Spodoptera exigua.
\end{abstract}

\begin{abstract}
Thirty Atriplex lines were examined for potential habitat improvement and phytoremediation of selenium (Se) contaminated sites. Studies were conducted to determine the biomass production, Se accumulation, and resistance of each line to the beet armyworm, Spodoptera exigua, an agriculturally important insect. Plants were tested using three salinity treatments: (1) control, no Se; (2) $\mathrm{NaCl}$ and $\mathrm{CaCl}_{2}$ salts and $1 \mathrm{mg} \mathrm{l}^{-1} \mathrm{Se}(12.7 \mu \mathrm{M})$ added as sodium selenate; and (3) iso-osmotic to treatment 2 containing high concentrations of sulfate and $1 \mathrm{mg} \mathrm{l}^{-1} \mathrm{Se}$ added as sodium selenate. Insect bioassays measured survival, growth, and development. Atriplex patula, A. spongiosa 415862, A. hortensis, A. hortensis 379088 and A. hortensis 379092 were among the top biomass producers and Se accumulators, yet they exhibited significantly reduced insect growth, development, and survival. High background sulfate strongly reduced Se accumulation, suggesting that phytoremediation potential is greatest in saline areas having low to moderate sulfate levels. However, these lines grew well in high salinity soils, indicating possible use as a self-seeding cover crop to improve habitat. All plant lines grown in control and high sulfate salinity treatments are acceptable oviposition sites for S. exigua, indicating that these plants would help reduce populations of this key agricultural pest. (C) 2002 Elsevier Science Ltd. All rights reserved.
\end{abstract}

Keywords: Atriplex; Herbivory; Integrated production program; Phytoremediation; Selenium; Spodoptera exigua; Saline drainage

\section{Introduction}

Soil selenium (Se) accumulation associated with agricultural irrigation, geochemical processes, mining, and a variety of other industrial sources frequently results in significant effects on animal health (Lemly, 1997). Although $\mathrm{Se}$ is an essential trace nutrient important to humans and most other animals as an antioxidant (Mayland, 1994), toxicity occurs at high concentrations due to replacement of sulfur with Se in amino acids resulting in incorrect folding of the protein and consequently nonfunctional proteins and enzymes (Daniels, 1996; Lemly, 1998). Remediation strategies include removal of soil Se through microbial and plant volatilization, and by plant accumulation, harvest, and

* Corresponding author. Tel.: + 1-909-787-4297; fax: + 1-909-7875624.

E-mail address: danel.vickerman@ucr.edu (D.B. Vickerman). removal (Khattak et al., 1991; Nyberg, 1991; Bañuelos et al., 1996; Wu et al., 1996; Losi and Frankenberger, 1997). Use of plants in Se-remediation programs will result in the availability of Se to insect herbivores, yet relatively little is known of the response of herbivorous insects to Se in plants.

Previous studies using artificial diets for an insect herbivore indicated that even low levels of Se can increase developmental times and mortality rates of the beet armyworm, Spodoptera exigua (Hübner) (Lepidoptera: Noctuidae) an agriculturally important pest insect (Trumble et al., 1998). This species demonstrated a preference for diets without sodium selenate or sodium selenite, but no preference was detected between diets with selenocystine or selenomethionine versus untreated controls (Vickerman and Trumble, 1999). Possible biotransfer of Se from plants to insects may not only have consequences for the pest insects (Trumble et al., 1998), but also for vertebrates and invertebrates that 
feed on insect herbivores (Wu et al., 1994). Unfortunately, data on effectiveness of cultivated and uncultivated plants in Se accumulation and as hosts for pest insects are minimal (Bañuelos et al., 1999).

Plants in the genus Atriplex (Chenopodiaceae) have been proposed as possible candidates for phytoremediation of Se. These plants could be useful both in managing the highly saline drainage water from farming operations and in the low salinity watersheds associated with point sources such as mining or sulfuric acid production plants. In the San Joaquin Valley (SJV) of California Se levels are as high as $2 \mathrm{mg}^{-1}$ Se in drainage water (Deverel et al., 1994), a concentration which potentially poses a health threat to humans and other animals (Lemly, 1997). These drainage waters are typically high in $\mathrm{Na}_{2} \mathrm{SO}_{4}$-dominant salts and are Se-laden, thus prohibiting their disposal into drainage channels and waterways.

Preliminary studies have shown that two species of Atriplex, A. patula and A. nummularia, can be grown in the SJV using drainage water as the only source for irrigation (Hoffman and Shannon, 1986; Watson and O'Leary, 1993). Additionally, recent studies have shown that A. hortensis (red orach), a salad green, also has a high salt tolerance as compared to other vegetables (Wilson et al., 2000). Because $\mathrm{Na}_{2} \mathrm{SO}_{4}$-dominant salts can reduce the uptake of Se due to competitive inhibition, it is important that plants chosen for Se remediation programs in the SJV are able to accumulate and volatilize Se in the presence of the high sulfate salinities characteristic of SJV drainage water (Grieve et al., 1999, 2001). For other point sources of Se contamination (mining, coal fly ash, oil refinery and electric utility discharge, or sulfuric acid production plants), the concerns related to elevated sulfate salinity are not important.

Atriplex spp. grow during winter and spring under dryland conditions in California, but can be grown during the summer irrigated conditions. At least 30 different species of Atriplex are native to California. However, some Atriplex species are hosts for S. exigua (Vickerman and Trumble, personal observation). The objectives of this research were to screen Atriplex lines for (1) Se uptake, (2) biomass accumulation and, (3) identification of the most favorable plant lines that would not support population development of a key insect pest.

\section{Materials and methods}

\subsection{Plants}

Atriplex germplasm was collected through both commercial sources and the Western Regional Plant Introduction Station, USDA, ARS, National Plant Germplasm System, Pullman, WA. All plants were grown in sand cultures at the USDA Salinity Laboratory outdoor facilities in Riverside CA, using cement containers $(2.0 \times 0.82 \times 0.85 \mathrm{~m})$ that were irrigated daily from 1740 $\mathrm{L}$ reservoirs containing treatment solutions (see Wilson et al., 2000). Sixty-two Atriplex lines were examined (M.C. Shannon et al. unpublished) and the most promising 30 lines were tested in insect bioassays. Assays were conducted in sets of ten plant lines and each set was consecutively numbered as test 1 , test 2 , and test 3 . All tests were conducted from January to March 2000. The average solar radiation during this time was 315 $\mathrm{Ly} / \mathrm{dy}$ with a minimum of $70 \mathrm{Ly} / \mathrm{dy}$ and a maximum of $569 \mathrm{Ly} / \mathrm{dy}$. The average temperature was $13.3{ }^{\circ} \mathrm{C}$ with a minimum of $7.8^{\circ} \mathrm{C}$ and a maximum of $21.1^{\circ} \mathrm{C}$.

Ten replicates (individual plants) of each plant line were grown in nutrient solution in three treatments. Nutrient solutions contained: $12.0 \mathrm{mM} \mathrm{Ca}, 7.5 \mathrm{mM} \mathrm{Mg}$, $4.0 \mathrm{mM} \mathrm{K}, 40 \mathrm{mM} \mathrm{SO}, 31.5 \mathrm{mM} \mathrm{Cl}, 4.0 \mathrm{mM} \mathrm{NO}_{3}$, $0.170 \mathrm{mM} \mathrm{P}_{4}, 50 \mu \mathrm{M} \mathrm{Fe}$ as sodium ferric diethlyenetriamine pentaacetate, $23 \mu \mathrm{M} \mathrm{H}_{3} \mathrm{BO}_{3}, 5 \mu \mathrm{M} \mathrm{MnSO}_{4}, 0.4$ $\mu \mathrm{M} \mathrm{ZnSO}_{4}, 0.2 \mu \mathrm{M} \mathrm{CuSO}_{4}, 0.1 \mu \mathrm{M} \mathrm{H}_{2} \mathrm{MoO}_{4}$. Treatments included: (1) a control, containing tap water plus nutrients with no $\mathrm{Se}(\mathrm{EC} \sim 9 \mathrm{dS} / \mathrm{m})$; (2) $\mathrm{Se}+\mathrm{Cl}$, containing nutrients and added $\mathrm{NaCl}$ and $\mathrm{CaCl}_{2}$ salts $(76$ $\mathrm{mM} \mathrm{Ca}, 160 \mathrm{mM} \mathrm{Na}$; EC $\sim 37 \mathrm{dS} / \mathrm{m})$ and $1 \mathrm{mg}^{-1} \mathrm{Se}$ $(12.7 \mu \mathrm{M})$ added as sodium selenate; and (3) $\mathrm{Se}+\mathrm{Cl}+\mathrm{SO}_{4}$, using simulated $\mathrm{SJV}$ drainage water (30 $\mathrm{mM} \mathrm{Mg}, 260 \mathrm{mM}$, Na, $120 \mathrm{mM} \mathrm{SO}_{4}, 126 \mathrm{mM} \mathrm{Cl}$; $\mathrm{EC} \sim 33 \mathrm{dS} / \mathrm{m}$ ) containing high amounts of sulfate, plus $1 \mathrm{mg}^{-1}$ Se added as sodium selenate.

Plants' shoots were harvested, washed in deionized water, dried in a forced air oven at $70{ }^{\circ} \mathrm{C}$ for $72 \mathrm{~h}$ and weighed. Leaf samples were collected and analyzed for $\mathrm{Se}$ by first using acid digestion with the $\mathrm{HNO}_{3} / \mathrm{H}_{2} \mathrm{O}_{2} /$ $\mathrm{HCl}$ procedure described by Bañuelos and Akohoue (1994), and then quantified using atomic absorption with an automatic vapor accessory.

Alfalfa (Medicago sativa L.) was grown in sand cultures in the UC Riverside Entomology Department greenhouses and irrigated daily with modified half strength Hoagland's nutrient solution (Khattak et al., 1991). Since alfalfa is known to be a host plant for $S$. exigua (Metcalf and Flint, 1962), it was used as an absolute control for all tests to document insect survival and development on a plant known to be an acceptable host. This also indicated that the insect colony did not vary in terms of survival potential or development rate over the course of the experiments. However, the alfalfa data were excluded from statistical analyses because this plant was not grown in the outdoor sand culture tanks.

\subsection{Insect development and survival bioassays}

S. exigua was chosen as a model insect for this study because it is a generalist feeder and a crop pest of economic importance throughout the USA, including areas 
where Se is a problem. In California, its host range includes native and introduced plants in the families Lilaceae, Fabaceae, Solanaceae, Malvaceae, Chenopodiaceae, Apiaceae, Asteraceae, and Amaranthaceae, that can be found in both cultivated and uncultivated areas (Metcalf and Flint, 1962; Peterson, 1962; Pearson et al., 1989). In addition, this species has highly mobile larvae, which select feeding sites by moving between plants (Berdegué et al., 1998).

All experiments were initiated with first instar larvae (standardized within $12 \mathrm{~h}$ of egg hatch) obtained from a laboratory colony maintained at $28 \pm 2{ }^{\circ} \mathrm{C}$ and $16: 8$ (light:dark) photoperiod. Insects were held in individually labeled containers and fed plant tissue ad libitum. Ten replicates of one insect each were tested for each of the plant line/treatment combinations in addition to the alfalfa control. Insect mortality, and the developmental stage of newly dead and all surviving larvae were recorded every other day. On day 30 , the developmental stage of insects which had not yet become adults was recorded and the experiment was terminated. Few insects will achieve the adult stage if development requires over 30 days (J.T. Trumble, personal observation). Developmental stages were numbered as follows: larval instars $1-5$ were stages $1-5$, stage 6 was the prepupal stage, stage 7 was the pupa, and stage 8 the adult moth. Developmental stage at death is important because this information can: (1) serve as an indicator of how much plant damage has occurred; consumption by this herbivore greatly increases after molting into stage four, so ideally plant lines would be chosen for their ability to suppress insect development at or before this stage; and (2) determine if the insects potentially live long enough for beneficial parasitoids to either complete development, or to be a resource for predators.

Percent survival to pupal and adult stages, mean days to insect pupation, and mean days to adult were calculated for insects in each plant line and treatment combinations. By comparison to the data on survival to the pupal stage, survival to the adult stage can be used to determine if additional mortality occurred during the pupal stage. Pupation is a rigorous process requiring increased production of enzymes and reorganization of proteins in insects. Since Se can replace sulfur in amino acids, resulting in nonfunctional proteins and enzymes (Daniels, 1996; Lemly, 1998) it is reasonable to expect that presence of Se may slow or impede insect development.

A measure of growth, the relative growth index (RGI; Zhang et al., 1993), was calculated for day eight, the day before any of the absolute control group developed into the pupal stage. This value measures herbivore growth rate by determining relative values of the developmental stage that could have been achieved on the control (alfalfa), versus what was achieved in the treatments.

\subsection{Insect oviposition bioassays}

Atriplex patula, A. spongiosa 415862, A. hortensis, A. hortensis 379088, A. hortensis 379092, and A. leucolada 355940 plants (maintained in $10.2 \mathrm{~cm}$ pots) from the control and $\mathrm{Se}+\mathrm{Cl}+\mathrm{SO}_{4}$ treatments were removed from sand culture tanks immediately after irrigation the day of the experiment. Four plants from each plant line (two from the $\mathrm{Se}+\mathrm{Cl}+\mathrm{SO}_{4}$ treatment and two from the control) were arranged in an alternating fashion in octagonal PVC cages covered in nylon organdy $(0.55 \mathrm{~m}$ high $\times 1.0 \mathrm{~m}$ width). Pots were buried in sand so the stems were exposed in a standardized fashion. Leaves were removed as necessary to standardize leaf areas available for oviposition.

The insects used in this study were also standardized, to the greatest extent possible. All insects originated from our laboratory colony (after Vickerman and Trumble, 1999). Pupae were sexed and separated by sex until adult emergence, at which time groups of four males and four females less than $48 \mathrm{~h}$ old were isolated in small mating chambers for $24 \mathrm{~h}$. Adults were then released into the PVC cages (four females per cage) and allowed to oviposit for $48 \mathrm{~h}$ ( 3 days and 2 nights). Each cage was a replicate. Plants were removed on day three; the total number of eggs were counted and the proportion of eggs laid on each treatment were calculated. All oviposition bioassays were conducted during June and early July 2001. The average solar radiation during this time was $644 \mathrm{Ly} / \mathrm{dy}$ with a minimum of $342 \mathrm{Ly} / \mathrm{dy}$ and a maximum of $725 \mathrm{Ly} / \mathrm{dy}$. The average temperature was $23.3^{\circ} \mathrm{C}$ with a minimum of $7.8^{\circ} \mathrm{C}$ and a maximum of $23.3^{\circ} \mathrm{C}$.

\subsection{Statistical analysis}

Analyses included two-way analysis of variance (GLM) and the protected least significant difference (LSD) post hoc tests (SAS, 1996). For the percent survival analyses a theoretical interaction term was calculated as described in Steel and Torrie (1980) in order to test for a significant interaction. Following a two-way analysis of variance (GLM, SAS 1996), the protected LSD post hoc procedure was used and the "no interaction' model was chosen. When interactions were present, no additional statistical analyses could be conducted (Steel and Torrie, 1980). Growth index (GI) and RGI (relative growth index) values were calculated as described by Zhang et al. (1993), where GI is calculated as:

$$
\mathrm{GI}=\frac{\sum_{i=1}^{i_{\max }}\left[n_{(i)} \times i\right]+\sum_{i=1}^{i_{\max }}\left[n_{(i)}^{\prime} \times(i-1)\right]}{N \times i_{\max }}
$$

where $i_{\max }=5$, the highest attainable instar of the insect at 8 days and $n=$ the number of insects in that instar 
and $N=$ total number of insects. RGI was determined as:

$\mathrm{RGI}=\frac{\mathrm{GI} \text { of the test group }}{\text { GI of the control group }}$

RGI values approaching one indicate better host plants; declining values indicate less favorable plants. Oviposition preference was analyzed using the Wilcoxon Signed Rank nonparametric procedure for paired comparisons (StatView, 1993; after Lance, 1992; Tallamy et al., 1997).

\section{Results}

\subsection{Plant biomass and Se accumulation}

Plant biomass serves as an indicator of salt and $\mathrm{Se}$ tolerance of the plant line. In the $\mathrm{Se}+\mathrm{Cl}+\mathrm{SO}_{4}$ treatment most characteristic of irrigation waters from the SJV, the plant lines A. hortensis 379088, A. hortensis 379092, A. hortensis, A. spongiosa 415862, A. patula, A. muelleri 224963, A. leptocarpa 342565, A. pseudocampanulata 342567, A. lindleyi 415865, and A. leucolada 355940 were in the top $30 \%$ of biomass accumulators (Table 1).

Selenium concentrations in leaf samples are reported for each plant line in each treatment (Table 2). In the $\mathrm{Se}+\mathrm{Cl}+\mathrm{SO}_{4}$ treatment most characteristic of irrigation waters from the SJV, plant lines $A$. hortensis 379088, $A$. hortensis 379092, A. inflata 330660, A. halimus 415863, A. leucolada 339807, A. semibaccata 299489, A. patula, A. lindleyi 415865 , and $A$. leucolada 355940 were the top $30 \%$ of Se accumulators. However, the high sulfate salinity treatment resulted in substantial reductions in Se accumulation on the order of one magnitude (Table 2). Many lines had only minimal biomass and low Se accumulation, and were therefore less suitable for use in phytoremediation, or as a ground cover for habitat improvement. These lines were therefore not considered in the subsequent insect studies.

\subsection{Insect development and survival}

As compared to survival in test 1 , insect survival to pupation was substantially reduced in all of the topperforming Atriplex lines (Fig. $1 \mathrm{a}-\mathrm{c}$ ). In addition, the $\mathrm{Se}+\mathrm{Cl}$ treatment and the $\mathrm{Se}+\mathrm{Cl}+\mathrm{SO}_{4}$ treatment had significantly reduced survival as compared to the control $\left(F_{2,18}=4.26, P<0.04\right)$. In plants assigned to test 1 , there was also a significant difference between plant lines $\left(F_{9,18}=4.50, P<0.01\right)$. In two plant lines, the $A$. hortensis and $A$. canescens 330658, the Se containing treatments allowed no survival. A similar pattern was observed in tests 2 and 3, but significant interaction
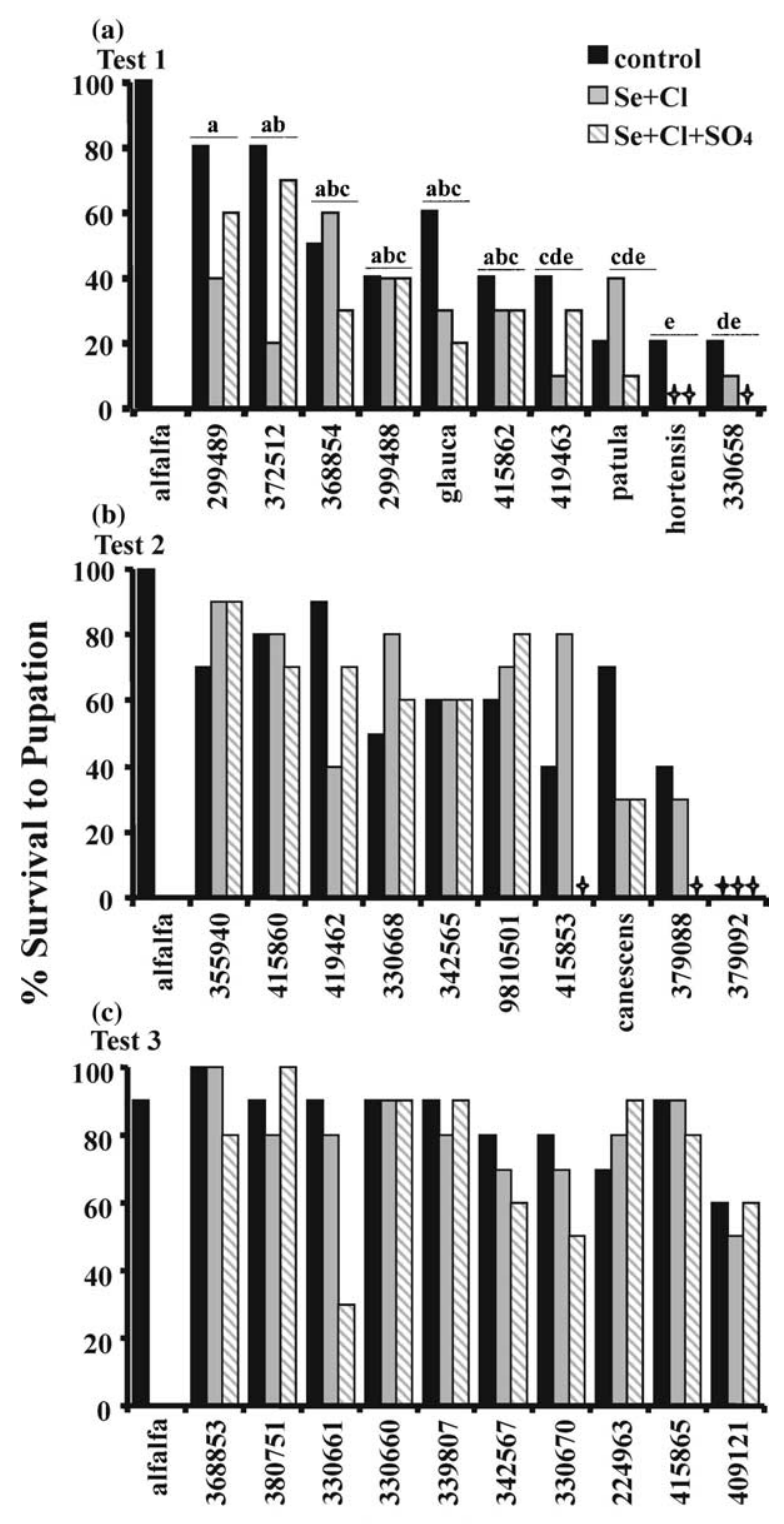

Plant Lines

Fig. 1. Percent survival to pupation for Spodoptera exigua larvae fed Atriplex plant lines from three irrigation treatments. Significant differences between plant lines are indicated by capital letters, values with the same letters are not significantly different. In test 1 , the control treatment was significantly different from both the $\mathrm{Se}+\mathrm{Cl}$ and the $\mathrm{Se}+\mathrm{Cl}+\mathrm{SO}_{4}$ treatments. Tests 2 and 3 had a significant plant line $\times$ salinity treatment interactions, so additional statistical comparisons were not possible. Plant lines which did not support survival to the pupal stage are indicated with the symbol '

terms $(P<0.05)$ precluded statistical analysis. However, line A. hortensis 379092 in test 2, was noteworthy for not allowing any insect to reach the pupal stage, regardless of the salinity treatment.

Survival to the adult stage was significantly different between treatments in test 1 , with the $\mathrm{Se}+\mathrm{Cl}+\mathrm{SO}_{4}$ treatment causing the most mortality $\left(F_{2,18}=3.82\right.$, $P<0.05$; Fig. 2 a). Insect survival was significantly decreased in six of the plant lines bioassayed in test 1 
Table 1

Dry plant weight of Atriplex plant lines tested in bioassays from three salinity treatments

\begin{tabular}{|c|c|c|c|c|c|}
\hline \multirow[t]{2}{*}{ Species } & \multirow[t]{2}{*}{ Line } & \multicolumn{3}{|c|}{ Dry wt/plant (g) } & \multirow[t]{2}{*}{ Origin } \\
\hline & & Control & $\mathrm{Se}+\mathrm{Cl}$ & $\mathrm{Se}+\mathrm{Cl}+\mathrm{SO}_{4}$ & \\
\hline \multicolumn{6}{|l|}{ Harvest 1} \\
\hline A. hortensis & 379088 & 42.557 & 11.760 & 16.457 & WRPIS \\
\hline A. hortensis & 379092 & 15.268 & 13.383 & 12.427 & WRPIS \\
\hline A. hortensis & hortensis & 13.865 & 5.495 & 10.885 & J. L. Hudson \\
\hline A. spongiosa & 330668 & 7.317 & 4.045 & 6.589 & WRPIS \\
\hline A. hortensis & 372512 & 11.717 & 5.828 & 4.617 & WRPIS \\
\hline A. glauca & glauca & 5.226 & 3.316 & 4.073 & Carter seeds \\
\hline A. inflata & 330660 & 1.710 & 1.655 & 3.999 & WRPIS \\
\hline A. halimus & 415853 & 3.123 & 1.221 & 3.433 & WRPIS \\
\hline A. suberecta & 368854 & 7.494 & 1.407 & 2.911 & WRPIS \\
\hline A. canescens & canescens & 0.862 & 0.421 & 0.790 & Carter seeds \\
\hline \multicolumn{6}{|l|}{ Harvest 2} \\
\hline A. spongiosa & 415862 & 20.248 & 0.572 & 14.298 & WRPIS \\
\hline A. patula & patula & 13.357 & 7.533 & 9.800 & $\mathrm{~S} \& \mathrm{~S}$ seeds \\
\hline A. semibaccata & 415860 & 4.463 & 1.220 & 7.953 & WRPIS \\
\hline A. semibaccata & 368853 & 5.550 & 1.388 & 6.267 & WRPIS \\
\hline A. muelleri & 380751 & 8.563 & 2.663 & 5.387 & WRPIS \\
\hline A. nummularia & 419462 & 5.109 & 1.411 & 4.074 & WRPIS \\
\hline A. leucolada & 339807 & 3.555 & 0.610 & 2.727 & WRPIS \\
\hline A. nummularia & 419463 & 4.377 & 2.726 & 2.660 & WRPIS \\
\hline A. canescens & canescens & 1.998 & 0.660 & 1.411 & Carter seeds \\
\hline A. semibaccata & 299489 & 5.097 & 1.715 & 1.312 & WRPIS \\
\hline A. semibaccata & 299488 & 4.206 & 1.261 & 0.602 & WRPIS \\
\hline \multicolumn{6}{|l|}{ Harvest 3} \\
\hline A. muelleri & 224963 & 25.850 & 25.390 & 42.170 & WRPIS \\
\hline A. leptocarpa & 342565 & 20.620 & 2.660 & 32.490 & WRPIS \\
\hline A. pseudocampanulata & 342567 & 10.220 & 13.510 & 28.285 & WRPIS \\
\hline A. lindleyi & 415865 & 22.580 & 22.360 & 21.050 & WRPIS \\
\hline A. leucolada & 355940 & 29.940 & 5.580 & 12.300 & WRPIS \\
\hline A. lentiformis & 409121 & 7.509 & 1.464 & 5.916 & WRPIS \\
\hline A. canescens & canescens & 4.094 & 1.287 & 3.478 & Carter seeds \\
\hline unknown sp. & 330670 & 5.065 & 2.405 & 3.013 & WRPIS \\
\hline A. lentiformis & 330661 & 2.379 & 1.540 & 2.932 & WRPIS \\
\hline A. hortensis & NSSL 9810501 & 1.613 & 0.712 & 0.717 & NSSL \\
\hline A. canescens & 330658 & 8.572 & 0.037 & 0.575 & WRPIS \\
\hline
\end{tabular}

a WRPIS, Western Regional Plant Introduction System, Pullman, WA, part of the USDA, ARS, National Plant Germplasm System.

$\left(F_{9,18}=3.87, P<0.01\right)$. The significant interaction terms in tests 2 and $3(P<0.05)$ precluded statistical comparisons. However, because the patterns of survival to the adult stage (Fig. 2a-c) were nearly identical to the patterns of survival to the pupal stage (Fig. 1a-c), we can conclude that most mortality occurred during the larval stage, rather than during pupation.

Development stage at death varied for insects depending on the plant line and salinity treatment (Fig. 3 a-c). In the plant lines examined in test 1 , differences were significant between salinity treatments $\left(F_{2,270}=\right.$ $4.31, P<0.02)$, with the Se treatments causing insects to die earlier in their life cycles. Differences in developmental stage at death were also significant between plant lines $\left(F_{9,270}=7.84, P<0.01\right)$. The mean developmental stage at death was before stage four in the
$\mathrm{Se}+\mathrm{Cl}+\mathrm{SO}_{4}$ treatment for plant lines $A$. semibaccata 299488, A. glauca, A. patula, A. hortensis, and A. canescens 330658 from test 1 . There were no significant plant line $\times$ salinity treatment interactions in test 1 .

Similarly, in test 2, the between plant line differences were significant $\left(F_{9,270}=10.27, P<0.01\right.$, Fig. $\left.3 b\right)$. Feeding on $A$. halimus 415853, A. hortensis 379088 , and $A$. hortensis 379092 resulted in death before stage four. However, the most rapid mortality was seen on plant line A. hortensis 379092. Differences between salinity treatments were not significant. Plant $\times$ salinity treatment interactions also were not significant.

In test 3 plant line $\times$ salinity treatment interactions were significant $\left(F_{18,270}=1.83, P<0.03\right)$, so additional statistical analyses were not possible. This test included few plant lines that appeared to offer substantial reductions 
Table 2

Selenium concentrations of Atriplex plant lines tested in bioassays from three salinity treatments

\begin{tabular}{|c|c|c|c|c|}
\hline \multirow[t]{2}{*}{ Species } & \multirow[t]{2}{*}{ Line } & \multicolumn{3}{|c|}{ Total Se (mg/kg) } \\
\hline & & Control & $\mathrm{Se}+\mathrm{Cl}$ & $\mathrm{Se}+\mathrm{Cl}+\mathrm{SO}_{4}$ \\
\hline \multicolumn{5}{|l|}{ Harvest 1} \\
\hline A. hortensis & 379088 & 0.08 & 40.80 & 3.04 \\
\hline A. hortensis & 379092 & 0.14 & 40.00 & 2.70 \\
\hline A. inflata & 330660 & 0.50 & 66.00 & 2.40 \\
\hline A. halimus & 415853 & 0.16 & 82.80 & 2.27 \\
\hline A. spongiosa & 330668 & 0.14 & 38.20 & 1.91 \\
\hline A. hortensis & 372512 & 0.17 & 27.00 & 1.73 \\
\hline A. glauca & glauca & 0.16 & 61.50 & 1.58 \\
\hline A. hortensis & hortensis & 0.19 & 39.70 & 1.54 \\
\hline A. canescens & canescens & 0.14 & 42.40 & 1.54 \\
\hline A. suberecta & 368854 & 0.10 & 33.40 & 1.40 \\
\hline \multicolumn{5}{|l|}{ Harvest 2} \\
\hline A. leucolada & 339807 & 0.40 & 39.10 & 3.20 \\
\hline A. semibaccata & 299489 & 0.30 & 33.80 & 2.30 \\
\hline A. patula & patula & 0.10 & 37.60 & 2.00 \\
\hline A. spongiosa & 415862 & 0.09 & 39.70 & 1.96 \\
\hline A. canescens & canescens & 0.15 & 48.20 & 1.95 \\
\hline A. semibaccata & 368853 & 0.10 & 34.70 & 1.90 \\
\hline A. nummularia & 419462 & 0.14 & 49.80 & 1.82 \\
\hline A. semibaccata & 299488 & 0.30 & 32.20 & 1.80 \\
\hline A. semibaccata & 415860 & 0.15 & 35.10 & 1.77 \\
\hline A. muelleri & 380751 & 0.40 & 40.10 & 1.70 \\
\hline A. nummularia & 419463 & 0.10 & 33.20 & 1.20 \\
\hline \multicolumn{5}{|l|}{ Harvest 3} \\
\hline A. lindleyi & 415865 & 0.24 & 41.16 & 2.61 \\
\hline A. leucolada & 355940 & 0.12 & 65.25 & 2.11 \\
\hline A. leptocarpa & 342565 & 0.19 & 47.76 & 1.45 \\
\hline unknown sp. & 330670 & 0.15 & 45.00 & 1.42 \\
\hline A. pseudocampanulata & 342567 & 0.21 & 35.16 & 1.42 \\
\hline A. canescens & canescens & 0.17 & 48.70 & 1.41 \\
\hline A. lentiformis & 409121 & 0.22 & 47.88 & 1.40 \\
\hline A. muelleri & 224963 & 0.20 & 33.24 & 1.38 \\
\hline A. hortensis & NSSL 9810501 & 0.19 & 42.24 & 1.25 \\
\hline A. lentiformis & 330661 & 0.16 & 45.00 & 1.15 \\
\hline A. canescens & 330658 & - & - & - \\
\hline
\end{tabular}

in developmental stage (Fig. 3c). Only A. lentiformis 330661 consistently caused larval death before stage four.

The relative growth index (RGI) indicated that several Atriplex lines that supported some insect growth did so at a greatly reduced development rate, as compared to the alfalfa control (Fig. $4 \mathrm{a}-\mathrm{c}$ ). Differences in the RGI between plant lines were significant for plant lines in test $1\left(F_{9,270}=5.78, P<0.01\right)$ and test 2 $\left(F_{9,270}=7.44, P<0.01\right)$, and between salinity treatments in test 2 ; the no Se control plants grew significantly faster than plants in Se salinity treatments $\left(F_{2,270}=5.14\right.$, $P<0.01$ ). Plant lines $A$. canescens 330658 from test 1 , and A. canescens and A. hortensis 379092 from test 2 significantly reduced insect development in the $\mathrm{Se}+\mathrm{Cl}+\mathrm{SO}_{4}$ treatment, as measured by RGI. Test 3

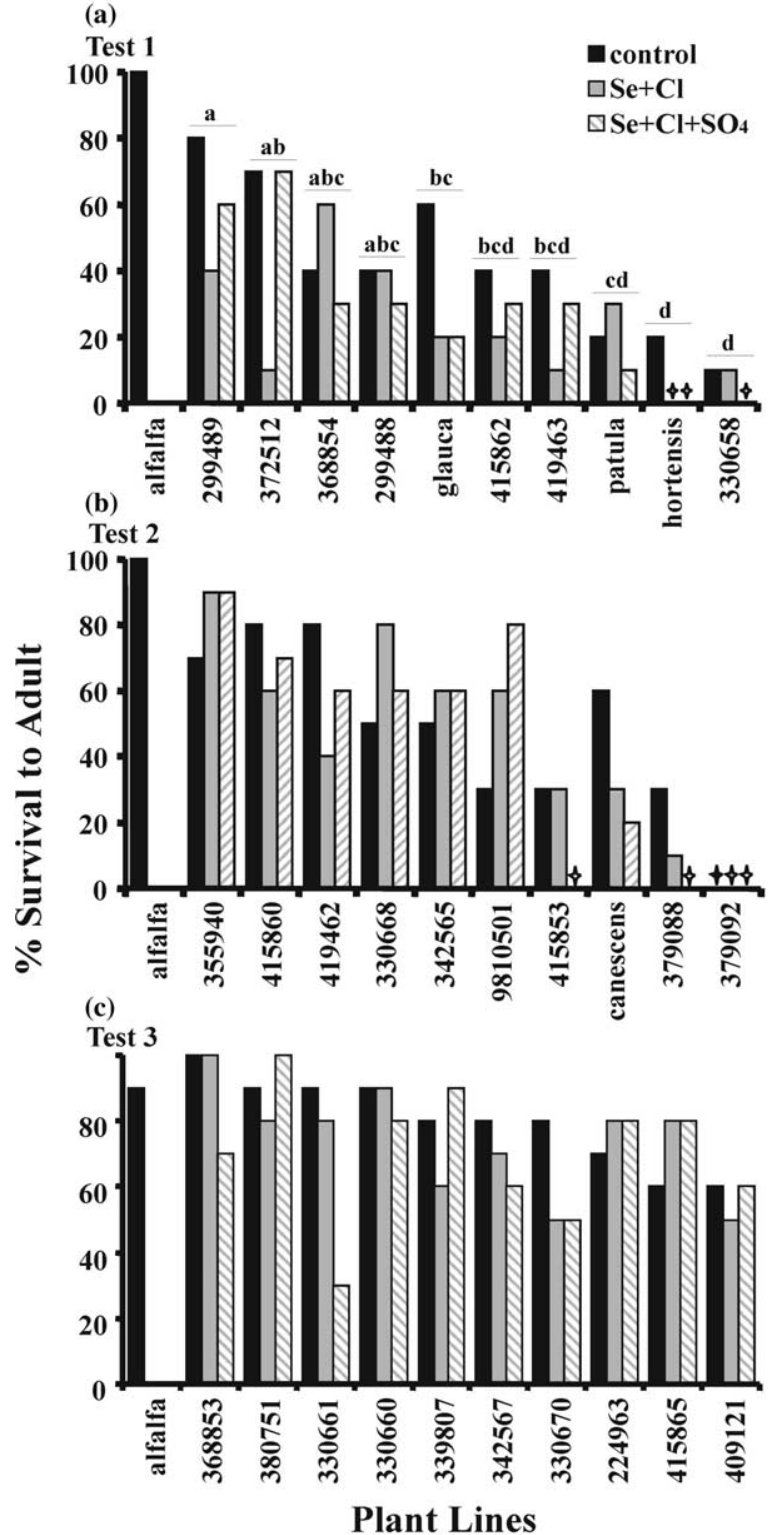

Fig. 2. Percent survival to adult for Spodoptera exigua larvae fed Atriplex plant lines from three irrigation treatments. Significant differences between plant lines are indicated by capital letters, values with the same letters are not significantly different. In test 1 , the control treatment was significantly different from the $\mathrm{Se}+\mathrm{Cl}+\mathrm{SO}_{4}$ treatment. Tests 2 and 3 had a significant plant line $\times$ salinity treatment interactions, so additional statistical comparisons were not possible. Plant lines which did not support survival to the adult stage are indicated with the symbol

plant line $\times$ salinity treatment interactions were significant $\left(F_{18,270}=1.99, P<0.02\right)$.

Day of death (Table 3 ) differed significantly between salinity treatments and between plant lines in test 1 $\left(F_{2,270}=5.13, \quad P<0.01 ; \quad F_{9,270}=6.90, \quad P<0.01\right)$, and between plant lines in test $2\left(F_{9,270}=7.99, P<0.01\right)$ and test $3\left(F_{9,270}=2.09, P<0.04\right)$. There were no significant plant line $\times$ salinity treatment interactions in any of the tests. Day of death on plants in both Se salinity treatments in test 1 was significantly earlier than on 
(a)

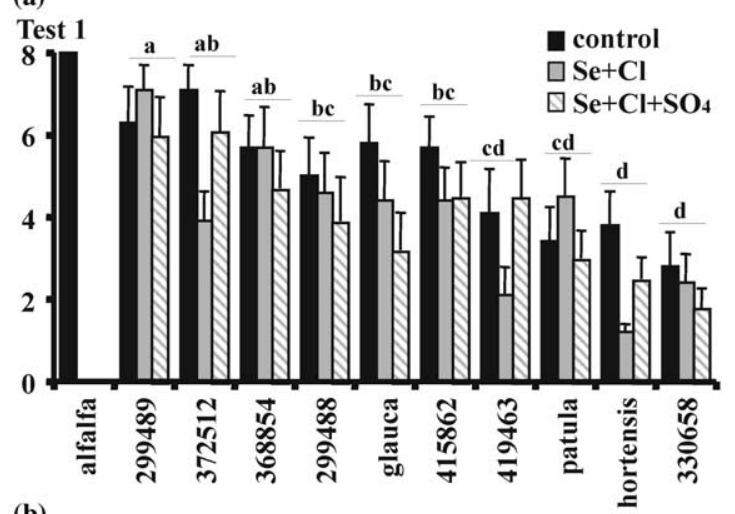

(b)
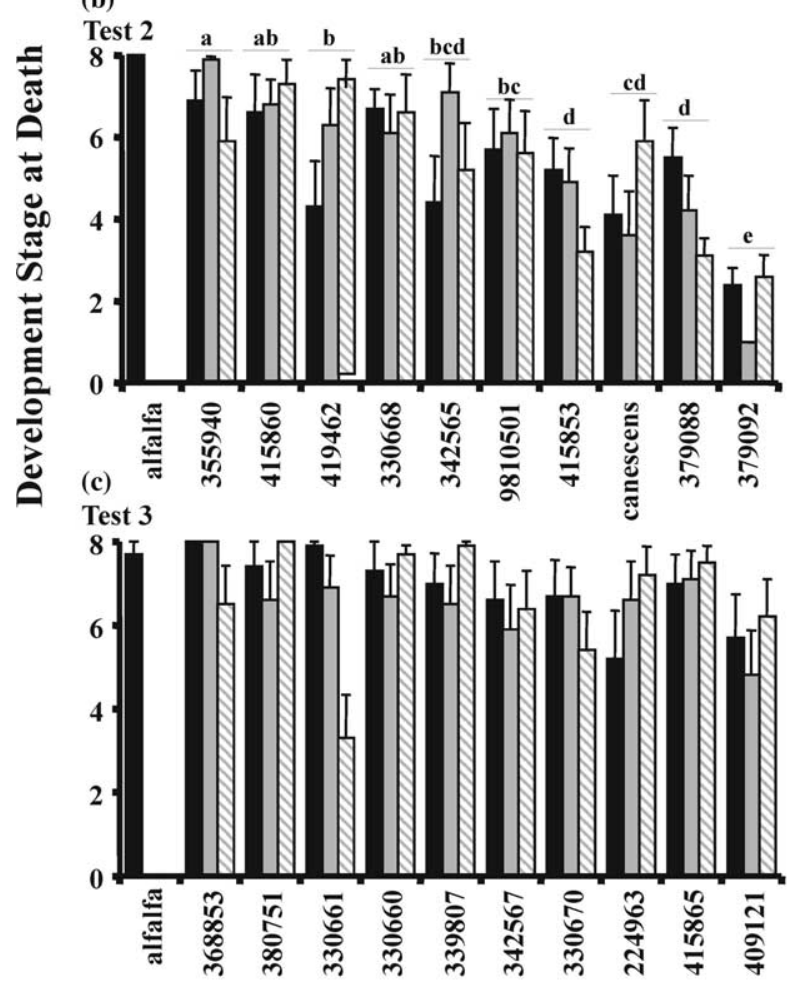

Plant Lines

Fig. 3. Development stage at death for Spodoptera exigua larvae fed Atriplex plant lines from three irrigation treatments. Significant differences between plant lines are indicated by capital letters, values with the same letters are not significantly different. In tests 1 and 2, there were no significant treatment differences. Test 3 had a significant plant line $\times$ salinity treatment interaction, so additional statistical comparisons were not possible.

control plants. For plant lines A. glauca, A. hortensis, and A. canescens 330658 from test 1, A. halimus 415853, and A. hortensis 379092 from test 2, and A. lentiformis 330661 from test 3 , the average day of death was before the mean day to pupation for insects in the control group that was fed alfalfa. For those insects which die, a relatively early day of death reduces the amount of time the insect is available to the next trophic level, particularly predators, and so reduces the potential for Se biotransfer.
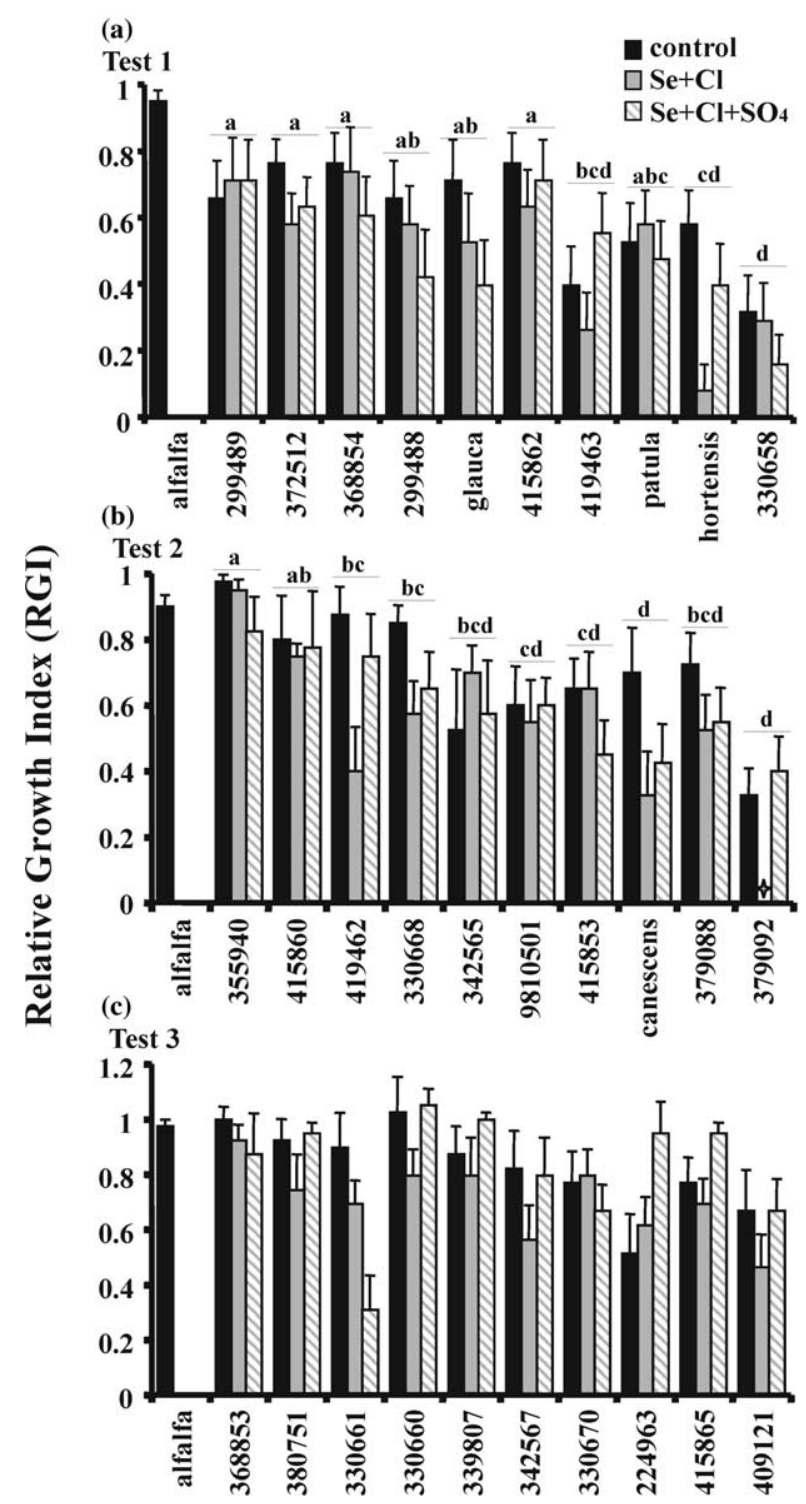

Plant Lines

Fig. 4. Relative growth index for Spodoptera exigua larvae fed Atriplex plant lines from three irrigation treatments. Significant differences between plant lines are indicated by capital letters, values with the same letters are not significantly different. In test 1 , there were no significant treatment differences. In test 2 , the control treatment was significantly different from the $\mathrm{Se}+\mathrm{Cl}+\mathrm{SO}_{4}$ treatment. Test 3 had a significant plant line $\times$ salinity treatment interaction, so additional statistical comparisons were not possible.

Mean days to pupation were included specifically to establish if any plants were toxic primarily to larvae. Toxicity could result in either death or an increase in developmental time. Insects that completed development to the pupal stage varied in their mean days to pupation between plant lines and between salinity treatments (Table 4). In plants examined in test 1 , these differences were significant between salinity treatments $\left(F_{2,76}=5.26, P<0.01\right)$ and between plant lines $\left(F_{9,76}=4.08, \quad P<0.01\right)$. Mean days to pupation on 
Table 3

Comparison of day of death for Spodoptera exigua larvae fed Atriplex plant lines from three salinity treatments

\begin{tabular}{|c|c|c|c|c|c|}
\hline \multirow[t]{2}{*}{ Species } & \multirow[t]{2}{*}{ Line } & \multicolumn{3}{|c|}{ Mean day of death ${ }^{\mathrm{a}}$} & \\
\hline & & Control & $\mathrm{Se}+\mathrm{Cl}$ & $\mathrm{Se}+\mathrm{Cl}+\mathrm{SO}_{4}$ & \\
\hline Test 1 & & $\mathrm{a}$ & $\mathrm{b}$ & $\mathrm{b}$ & \\
\hline M. sativa & (alfalfa) & 30.0 & & & \\
\hline A. semibaccata & 299489 & 22.6 & 27.4 & 22.8 & $\mathrm{a}$ \\
\hline A. hortensis & 372512 & 27.7 & 18.8 & 23.4 & $a b$ \\
\hline A. suberecta & 368854 & 23.8 & 23.6 & 16.8 & $a b c$ \\
\hline A. semibaccata & 299488 & 21.0 & 19.4 & 16.0 & bcde \\
\hline A. glauca & glauca & 23.0 & 16.6 & 9.2 & def \\
\hline A. spongiosa & 415862 & 21.4 & 19.8 & 19.6 & abcd \\
\hline A. nummularia & 419463 & 16.4 & 9.2 & 17.6 & ef \\
\hline A. patula & patula & 14.4 & 20.2 & 13.6 & cdef \\
\hline A. hortensis & hortensis & 18.8 & 3.4 & 11.8 & fg \\
\hline A. canescens & 330658 & 12.2 & 9.4 & 4.4 & $\mathrm{~g}$ \\
\hline Test 2 & & $\mathrm{a}$ & $\mathrm{a}$ & $\mathrm{a}$ & \\
\hline M. sativa & (alfalfa) & 30.0 & & & \\
\hline A. leucolada & 355940 & 24.4 & 29.4 & 27.2 & $\mathrm{a}$ \\
\hline A. semibaccata & 415860 & 24.8 & 26.8 & 22.2 & $\mathrm{ab}$ \\
\hline A. nummularia & 419462 & 15.4 & 24.4 & 27.6 & $a b c$ \\
\hline A. spongiosa & 330668 & 23.0 & 23.4 & 24.8 & $\mathrm{ab}$ \\
\hline A. leptocarpa & 342565 & 16.8 & 26.0 & 19.0 & bcd \\
\hline A. hortensis & $\begin{array}{l}\text { NSSL } \\
9810501\end{array}$ & 20.8 & 18.4 & 21.6 & bcd \\
\hline A. halimus & 415853 & 21.6 & 17.2 & 13.6 & $\mathrm{ab}$ \\
\hline A. canescens & canescens & 30.0 & 15.2 & 12.4 & $\mathrm{~d}$ \\
\hline A. hortensis & 379088 & 20.4 & 17.4 & 15.6 & $\mathrm{~cd}$ \\
\hline A. hortensis & 379092 & 8.6 & 4.0 & 11.2 & $\mathrm{e}$ \\
\hline Test 3 & & $\mathrm{a}$ & $\mathrm{a}$ & $\mathrm{a}$ & \\
\hline M. sativa & (alfalfa) & 28.8 & & & \\
\hline A. semibaccata & 368853 & 30.0 & 30.0 & 25.0 & $\mathrm{a}$ \\
\hline A. muelleri & 380751 & 27.4 & 24.6 & 30.0 & $a b$ \\
\hline A. lentiformis & 330661 & 28.4 & 26.8 & 12.2 & $\mathrm{bc}$ \\
\hline A. inflata & 330660 & 27.4 & 24.6 & 28.6 & $a b$ \\
\hline A. leucolada & 339807 & 25.8 & 23.0 & 28.2 & $a b$ \\
\hline A. pseudocampanulata & 342567 & 25.0 & 21.8 & 24.8 & $a b c$ \\
\hline unknown sp. & 330670 & 24.8 & 24.2 & 20.8 & $\mathrm{bc}$ \\
\hline A. muelleri & 224963 & 19.4 & 24.4 & 27.2 & $a b c$ \\
\hline A. lindleyi & 415865 & 24.6 & 26.4 & 27.2 & $a b$ \\
\hline A. lentiformis & 409121 & 20.0 & 18.0 & 22.2 & $\mathrm{c}$ \\
\hline
\end{tabular}

control plants in test 1 , was significantly shorter than that for the $\mathrm{Se}+\mathrm{Cl}+\mathrm{SO}_{4}$ treatments, but there were no differences between the two Se treatments. In plants examined in tests 2 and 3 , plant line $\times$ salinity treatment interactions were significant $\left(F_{14,131}=2.30, P<0.01\right.$; $\left.F_{18,206}=1.93, P<0.02\right)$.

For those insects that made it to the adult stage, mean days to adult varied between plant lines and between salinity treatments (Table 5). Control insects fed alfalfa developed to adults in 20 days or less, while insects fed Atriplex lines had mean developmental times of as long as 28 days. In plants examined in test 1 , differences were significant between plant lines $\left(F_{9,69}=4.20, P<0.01\right)$, but not between treatments. In plants examined in tests 2 and 3, plant linexsalinity
Table 4

Comparison of mean days to pupation for Spodoptera exigua larvae fed Atriplex plant lines from three salinity treatments

\begin{tabular}{llllll}
\hline \multirow{2}{*}{ Species } & \multirow{2}{*}{ Line } & \multicolumn{4}{l}{ Mean days to pupation } \\
\cline { 3 - 5 } & & Control & $\mathrm{Se}+\mathrm{Cl}$ & $\mathrm{Se}+\mathrm{Cl}+\mathrm{SO}_{4}$ \\
\hline Test 1 & & $\mathrm{a}$ & $\mathrm{b}$ & $\mathrm{ab}$ & \\
M. sativa & (alfalfa) & 12.2 & & & \\
A. semibaccata & 299489 & 13.7 & 14.7 & 12.3 & $\mathrm{a}$ \\
A. hortensis & 372512 & 15.3 & 21.0 & 16.9 & $\mathrm{c}$ \\
A. suberecta & 368854 & 14.8 & 12.3 & 16.0 & $\mathrm{ab}$ \\
A. semibaccata & 299488 & 12.5 & 15.0 & 14.5 & $\mathrm{a}$ \\
A. glauca & glauca & 13.7 & 14.0 & 13.0 & $\mathrm{a}$ \\
A. spongiosa & 415862 & 16.0 & 18.0 & 15.3 & $\mathrm{bc}$ \\
A. nummularia & 419463 & 16.5 & 18.0 & 14.0 & $\mathrm{abc}$ \\
A. patula & patula & 15.0 & 18.5 & 18.0 & $\mathrm{c}$ \\
A. hortensis & hortensis & 18.0 & $\bullet \mathrm{b}$ & $\bullet$ & $\mathrm{c}$ \\
A. canescens & 330658 & 17.0 & 20.0 & $\bullet$ & $\mathrm{c}$
\end{tabular}

Test 2

M. sativa

A. leucolada

A. semibaccata

A. nummularia

A. spongiosa

A. leptocarpa

A. hortensis

A. halimus

A. canescens

A. hortensis

A. hortensis

$\begin{array}{llll}\text { (alfalfa) } & 12.6 & & \\ 355940 & 13 & 12.4 & 15.6 \\ 415860 & 12 & 14.3 & 12.6 \\ 419462 & 13.8 & 17.0 & 15.4 \\ 330668 & 12.9 & 16.3 & 14.3 \\ 342565 & 12.8 & 14.3 & 13.3 \\ \text { NSSL } & 15 & 15.3 & 17.3 \\ 9810501 & & & \\ 415853 & 18 & 15.3 & \bullet \\ \text { canescens } & 14.3 & 16.0 & 18.0 \\ 379088 & 17 & 21.3 & \bullet \\ 379092 & \bullet & \bullet & \bullet\end{array}$

Test 3

\begin{tabular}{lllll} 
M. sativa & (alfalfa) & 12.7 & & \\
A. semibaccata & 368853 & 12.6 & 13.4 & 12.3 \\
A. muelleri & 380751 & 12.7 & 13.5 & 14.2 \\
A. lentiformis & 330661 & 14.7 & 15.8 & 15.3 \\
A. inflata & 330660 & 13.8 & 14.6 & 14.0 \\
A. leucolada & 339807 & 12.7 & 13.0 & 12.2 \\
A. pseudocampanulata & 342567 & 13.0 & 15.0 & 14.0 \\
unknown sp. & 330670 & 14.0 & 15.7 & 14.4 \\
A. muelleri & 224963 & 14.3 & 13.5 & 12.4 \\
A. lindleyi & 415865 & 13.8 & 15.3 & 12.5 \\
A. lentiformis & 409121 & 14.0 & 14.4 & 13.3 \\
\hline
\end{tabular}

a Significant differences $(P<0.05)$ between treatments or between plants are indicated by letters a,b,c; values with the same letters are not different (LSD, SAS, 1996). Absence of letters is due to interactions that did not allow statistical comparisons for tests 2 and 3 .

b $\diamond=$ Plant lines which did not support survival to the pupal stage.

treatment interactions were significant $\left(F_{14,112}=2.88\right.$, $P<0.01 ; F_{18,191}=1.85$, and $\left.P<0.03\right)$, and no additional analyses were possible.

\subsection{Insect oviposition bioassays}

All plant lines were suitable for oviposition by S. exigua. No differences were found in proportion of eggs laid on control compared to $\mathrm{Se}+\mathrm{Cl}+\mathrm{SO}_{4}$ treated plants in the plant lines tested (Fig. 5; Atriplex patula, $n=6$, 
Table 5

Comparison of mean days to adult for Spodoptera exigua larvae fed Atriplex plant lines from three salinity treatments

\begin{tabular}{|c|c|c|c|c|c|}
\hline \multirow[t]{2}{*}{ Species } & \multirow[t]{2}{*}{ Line } & \multicolumn{3}{|c|}{ Mean days to adult ${ }^{\mathrm{a}}$} & \\
\hline & & Control & $\mathrm{Se}+\mathrm{Cl}$ & $\mathrm{Se}+\mathrm{Cl}+\mathrm{SO}_{4}$ & \\
\hline Test 1 & & $\mathrm{a}$ & $\mathrm{a}$ & $\mathrm{a}$ & \\
\hline M. sativa & (alfalfa) & 19.0 & & & \\
\hline A. semibaccata & 299489 & 21.1 & 21.0 & 19.7 & $a b$ \\
\hline A. hortensis & 372512 & 22.6 & 26.0 & 23.4 & $\mathrm{c}$ \\
\hline A. suberecta & 368854 & 19.5 & 19.7 & 22.7 & $\mathrm{a}$ \\
\hline A. semibaccata & 299488 & 19.5 & 22.0 & 19.3 & $\mathrm{a}$ \\
\hline A. glauca & glauca & 21.0 & 21.0 & 22.0 & $\mathrm{ab}$ \\
\hline A. spongiosa & 415862 & 22.5 & 24.0 & 22.0 & $\mathrm{bc}$ \\
\hline A. nummularia & 419463 & 23.0 & 26.0 & 22.0 & $\mathrm{c}$ \\
\hline A. patula & patula & 22.0 & 24.7 & 24.0 & $\mathrm{~cd}$ \\
\hline A. hortensis & hortensis & 24.0 & $\Delta^{b}$ & $\diamond$ & $\mathrm{cd}$ \\
\hline A. canescens & 330658 & 26.0 & 28.0 & $\diamond$ & $\mathrm{d}$ \\
\hline \multicolumn{6}{|l|}{ Test 2} \\
\hline M. sativa & (alfalfa) & 19.2 & & & \\
\hline A. leucolada & 355940 & 19.7 & 19.3 & 21.0 & \\
\hline A. semibaccata & 415860 & 17.8 & 20.8 & 19.4 & \\
\hline A. nummularia & 419462 & 20.0 & 23.5 & 22.0 & \\
\hline A. spongiosa & 330668 & 20.7 & 23.0 & 21.0 & \\
\hline A. leptocarpa & 342565 & 19.0 & 21.5 & 19.0 & \\
\hline A. hortensis & $\begin{array}{l}\text { NSSL } \\
9810501\end{array}$ & 22.0 & 22.7 & 24.0 & \\
\hline A. halimus & 415853 & 26.7 & 22.0 & $\diamond$ & \\
\hline A. canescens & canescens & 21.0 & 24.0 & 25.0 & \\
\hline A. hortensis & 379088 & 23.0 & 28.0 & $\diamond$ & \\
\hline A. hortensis & 379092 & $\diamond$ & $\diamond$ & $\diamond$ & \\
\hline \multicolumn{6}{|l|}{ Test 3} \\
\hline M. sativa & (alfalfa) & 20.2 & & & \\
\hline A. semibaccata & 368853 & 19.2 & 19.6 & 19.7 & \\
\hline A. muelleri & 380751 & 19.8 & 20.3 & 21.0 & \\
\hline A. lentiformis & 330661 & 21.3 & 23.0 & 22.0 & \\
\hline A. inflata & 330660 & 20.9 & 21.1 & 20.8 & \\
\hline A. leucolada & 339807 & 18.8 & 19.0 & 18.2 & \\
\hline A. pseudocampanulata & 342567 & 19.0 & 22.0 & 19.0 & \\
\hline unknown sp. & 330670 & 20.3 & 22.0 & 21.2 & \\
\hline A. muelleri & 224963 & 21.0 & 20.3 & 19.0 & \\
\hline A. lindleyi & 415865 & 20.0 & 23.0 & 19.5 & \\
\hline A. lentiformis & 409121 & 19.3 & 21.6 & 20.3 & \\
\hline
\end{tabular}

a Significant differences $(P<0.05)$ between treatments or between plants are indicated by letters a,b,c; values with the same letters are not different (LSD, SAS, 1996). Absence of letters is due to interactions that did not allow statistical comparisons for tests 2 and 3 .

b $\diamond=$ Plant lines which did not support survival to the adult stage.

$Z=-1.15, P=0.25 ;$ A. spongiosa $415862, n=5, Z=$ $-0.41, P=0.69 ; A$. hortensis, $n=5, Z=-1.10, P=0.27$; A. hortensis 379088, $n=2, Z=-1.34, P=0.18$; $A$. hortensis 379092, $n=5, Z=-0.67, P=0.50 ; A$. leucolada 355940, $n=5, Z=-0.14, P=0.89)$.

\section{Discussion}

Plant lines chosen for phytoremediation programs should have high biomass, high Se accumulation and/or

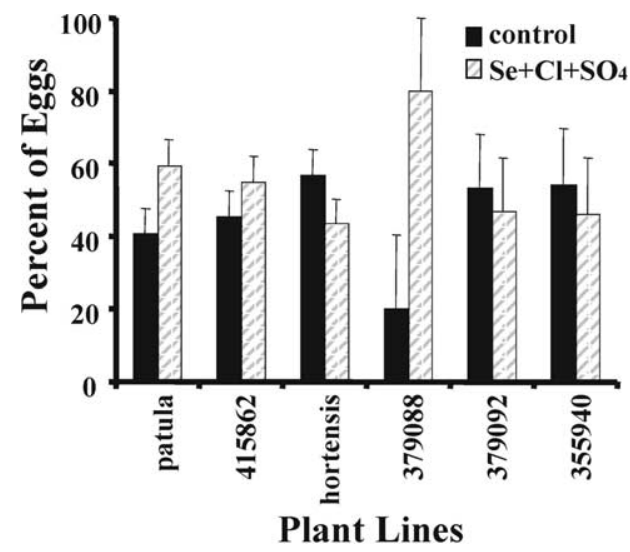

Fig. 5. Oviposition preference of Spodoptera exigua on selected Atriplex plant lines from two salinity treatments. No significant differences were found.

volatilization, and should not support the growth of agriculturally important insects into the adult stage. In our study, selenium accumulation by Atriplex lines was reduced in the presence of high sulfate levels. Therefore, these Atriplex lines have greater potential for Se-remediation of saline soils where the major anion in the substrate is not sulfate. Additional information on the amount of Se volatilized by these plants would be desirable, and it would allow a more comprehensive assessment of the phytoremediation potential of these Atriplex lines. Nonetheless, five Atriplex lines were identified that would provide a self-seeding ground cover, even in the presence of high sulfate salinity.

The presence of Se in irrigation water increased plant resistance to the insect tested in this model system, which is in agreement with the data generated for Indian mustard (Bañuelos et al., 1999). This suggests that Se may enhance plant resistance to the beet armyworm, but the literature is too limited to allow definitive generalizations.

Several plant lines with high biomass and Se accumulation in the $\mathrm{Se}+\mathrm{Cl}+\mathrm{SO}_{4}$ treatment such as $A$. lindleyi 415865 and $A$. leucolada 355940 allowed 90\% survival to adult eclosion, making them less suitable for either phytoremediation or for habitat improvement near agricultural regions. Although the plant lines $A$. glauca, A. nummularia 419463, A. canescens 330658, A. halimus 415853, A. canescens, and A. lentiformis 330661 suppress insect survival to $30 \%$ or less, and reduce insect development in the $\mathrm{Se}+\mathrm{Cl}+\mathrm{SO}_{4}$ treatment, they were considered less desirable because of low biomass production and low Se accumulation.

Several Atriplex plant lines show potential for use in phytoremediation in areas with low to moderate levels of sulfate salinity. Of the five plant lines that were in the top $30 \%$ of biomass producers and Se accumulators, $A$. hortensis 379088 and $A$. hortensis 379092 allowed no larvae to survive to pupation and only $10 \%$ of the insects fed $A$. patula survived. Other plant lines that 
justify further investigation include $A$. hortensis which reduced insect development and permitted no insect survival and was also in the top $60 \%$ of Se accumulators and the top $30 \%$ of plant biomass producers, and A. spongiosa 415862 which reduced insect survival by $70 \%$ and was in the top $30 \%$ of plant biomass producers and top $33 \%$ of Se accumulators. Thus, these plant lines would not be likely to host significant $S$. exigua populations, or allow substantial bioaccumulation.

Our results suggest that these Atriplex lines could improve grower participation in phytoremediation or habitat improvement programs by potentially reducing local populations of a key insect pest. These plant lines act as a 'sink' in which oviposition occurs, but larval development and survival are inhibited. However, the most promising plant lines should be further studied to determine their effects on other key insect pests such as Circulifer tenellus, an important vector of curly top virus found in many regions of the western USA having Se contamination.

\section{Acknowledgements}

We would like to thank M.D. Arias, W.G. Carson, G.S. Kund, and J.K. Young for their laboratory assistance; and J. Draper for synchronizing the germination and planting of the diverse lines, maintaining salinity and Se treatments, and maintaining irrigation of the plots. We would also like to thank R.J. Beaver of the Department of Statistics at the University of California Riverside for his statistical advice. We also appreciate the reviews of R.T. Cardé, W.G. Carson, G.S. Kund, and T.D. Paine. We gratefully acknowledge the Western Regional Plant Introduction Station, USDA, ARS, National Plant Germplasm System, Pullman, WA for providing most of the seed for plants used in this research. This work was supported by grants from the University of California Toxic Substances Research and Teaching Program, and the University of California Salinity Drainage Program.

\section{References}

Bañuelos, G.S., Akohoue, S., 1994. Comparison of wet digestion and microwave digestion on selenium and boron analysis in plant tissues. Comm. Soil Sci. \& Plant Anal. 25, 1655-1670.

Bañuelos, G.S., Tebbets, J.S., Johnson, J., Vail, P.V., Mackey, B., 1999. Survey of insects and biotransfer of selenium from plants used for phytoremediation. Int. J. Phytoremed. 1, 311-326.

Bañuelos, G.S., Zayed, A., Terry, N., Wu, L., Akohoue, S., Zambruzuski, S., 1996. Accumulation of selenium by different plant species grown under increasing sodium and calcium chloride salinity. Plant Soil 183, 49-59.

Berdegué, M., Reitz, S.R., Trumble, J.T., 1998. Host plant selection in Spodoptera exigua: do mother and offspring know best? Entomol. Exp. Appl. 89, 57-64.
Daniels, L.A., 1996. Selenium metabolism and bioavailability. Biol. Trace Element Res. 51, 185-199.

Deverel, S.J., Fio, J.L., Dubrovsky, N.M., 1994. Distribution and mobility of selenium in ground water in the Western San Joaquin Valley of California. In: Frankenberger Jr., W.T., Benson, S. (Eds.), Selenium in the Environment. Marcel Dekker, New York, pp. 157183.

Grieve, C.M., Suarez, D.L., Shannon, M.C., 1999. Effects of saline irrigation water composition on selenium accumulation by wheat. J. Plant Nutr. 22, 1443-1450.

Grieve, C.M., Poss, J.A., Suarez, D.L., Dierig, D.A., 2001. Lesquerella growth and selenium uptake affected by saline irrigation water composition. Ind. Crops Prod. 13, 57-65.

Hoffman, G.J., Shannon, M.C., 1986. Relating plant performance and soil salinity. Reclam. Reveg. Res. 5, 211-225.

Khattak, R.A., Page, A.L., Parker, D.R., Bakhtar, D., 1991. Accumulation and interactions of arsenic, selenium, molybdenum and phosphorus in alfalfa. J. Environ. Qual. 20, 165-168.

Lance, D.R., 1992. Odors influence choice of oviposition sites by Diabrotica virgifera virgifera (Coleoptera: Chrysomelidae). J. Chem. Ecol. 18, 1227-1237.

Lemly, A.D., 1997. Environmental implications of excessive selenium: a review. Biomed. Environ. Sci. 10, 415-435.

Lemly, A.D., 1998. Pathology of selenium poisoning in fish. In: Frankenberger Jr., W.T., Engberg, R.A. (Eds.), Environmental Chemistry of Selenium. Marcel Dekker, New York , pp. 281-296.

Losi, M.E., Frankenberger Jr., W.T., 1997. Bioremediation of selenium in soil and water. Soil Sci. 162, 692-702.

Mayland, H.F., 1994. Selenium in plant and animal nutrition. In: Frankenberger Jr., W.T., Benson, S. (Eds.), Selenium in the Environment. Marcel Dekker, New York, pp. 29-45.

Metcalf, C.L., Flint, W.P., 1962. Destructive and Useful Insects, Their Habits and Control. McGraw-Hill, San Francisco.

Nyberg, S., 1991. Multiple use of plants - studies on selenium incorporation in some agricultural species for the production of organic selenium compounds. Plant Foods Hum. Nutr. 41, 69-88.

Pearson, A.C., Sevacherian, V., Ballmer, G.P., Vail, P.V., Henneberry, T.J., 1989. Spring annual hosts of five noctuid pests in the Imperial valley of California (Lepidoptera: Noctuidae). J. Kans. Entomol. Soc. 61, 464- 470 .

Peterson, A., 1962. Larvae of Insects, an Introduction to Nearctic Species, Part I: Lepidoptera and Plant-Infesting Hymenoptera. Edwards Brothers, Ann Arbor.

SAS, 1996. SAS/STAT 6.12 for Macintosh. SAS Institute, Cary, NC. StatView, 1993. Albacus Concepts Inc., Berkeley, CA.

Steel, R.G.D., Torrie, J.H., 1980. Principles and Procedures of Statistics: A Biometric Approach. McGraw-Hill, New York.

Tallamy, D.W., Stull, J., Ehresman, N.P., Gorski, P.M., Mason, C.E., 1997. Cucurbitacins as feeding and oviposition deterrents to insects. Environ. Entomol. 26, 678-683.

Trumble, J.T., Kund, G.S., White, K.K., 1998. Influence of form and quantity of selenium on the development and survival of an insect herbivore. Environmental Pollution 101, 175-182.

Vickerman, D.B., Trumble, J.T., 1999. Feeding preferences of Spodoptera exigua in response to form and concentration of selenium. Arch. Insect Biochem. Physiol. 42, 64-73.

Watson, M., O'Leary, J., 1993. Performance of Atriplex species in the San Joaquin Valley, California, under irrigation and with mechanical harvests. Agric. Ecosys. Environ. 43, 255-266.

Wilson, C., Lesch, S.M., Grieve, C.M., 2000. Growth stage modulates salinity tolerance of New Zealand Spinach (Tetragonia tetragonoiides, Pall.) and Red Orach (Atriplex hortensis L.). Ann. Bot. 85, 501-509.

Wu, L., Enberg, A., Biggar, J.A., 1994. Effects of elevated selenium concentration on selenium accumulation and nitrogen fixation symbiotic activity of Melilotus indica L. Ecotoxicol. Environ. Safety $27,50-63$. 
Wu, L., Vanmantgem, P.J., Guo, X., 1996. Effects of forage plant and field legume species on soil selenium redistribution, leaching, and bioextraction in soils contaminated by agricultural drain water sediment. Arch. Environ. Contam. Toxicol. 31, 329-338.
Zhang, M., Chaduri, S.K., Kubo, I., 1993. Quantification of insect growth and its use in screening of naturally occurring insect control agents. J. Chem. Ecol. 19, 1109-1118. 